\title{
EFFECT OF INSULIN ON CARBOHYDRATE METABOLISM AND ON POTASSIUM IN THE FOREARM OF MAN *
}

\author{
By REUBIN ANDRES, MARCEL A. BALTZAN, GORDON CADER AND \\ KENNETH L. ZIERLER
}

(From the Department of Medicine, The Johns Hopkins University and Hospital, and The Baltimore City Hospitals, Baltimore, Md.)

(Submitted for publication July 27, 1961 ; accepted August 31, 1961)

We have described a technique for quantifying skeletal muscle metabolism in man in situ by measing blood flow through the forearm and appropriate arteriovenous differences in concentration of selected metabolites (1). The technique lends itself to analysis of local effects of hormones and other possibly potent agents. The agent can be injected into the brachial artery at constant rate with the solution of Evans blue dye used to measure blood flow. The quantity of the agent injected can be sufficiently large to exert a measurable effect in the forearm but sufficiently small so that, upon approximately 100 -fold dilution when forearm venous effluent mixes with blood in the heart and great vessels, there is no measurable systemic effect. There are, therefore, no detectable systemic counter-regulatory processes set in motion by the agent to complicate the primary response of the forearm to the agent itself.

It is the purpose of this report to describe the effects on forearm muscle metabolism of insulin administered in this fashion. We sought information concerning the following two problems.

1) Only a minor fraction of oxygen consumed by forearm muscle at rest can be accounted for by dissimilation of glucose abstracted from arterial blood (1). Is this because resting muscle is so poorly permeable to glucose? If glucose uptake is increased, say by exhibition of insulin, is oxidation of glucose enhanced necessarily?

2) Do the temporal and molar relations between glucose uptake and potassium uptake by muscle in response to insulin suggest that insulin-induced

* These studies were aided by Contract Nonr-248(34) (NR 101-241) between the Office of Naval Research, Department of the Navy, and The Johns Hopkins University; by Public Health Service Research Grant A-750, National Institute of Arthritis and Metabolic Diseases; and by a grant-in-aid from the Muscular Dystrophy Associations of America, Inc. Reproduction in whole or in part is permitted for any purpose of the United States Government. potassium movement is or is not secondary to the effect of insulin on glucose?

\section{METHODS}

Net uptake (or output) of a metabolite by forearm tissues was calculated by the equation $\dot{Q}=F(A-V)$, where $\dot{Q}$ is uptake (or output) of the metabolite in units of mass per minute per $100 \mathrm{ml}$ of forearm, $\mathrm{F}$ is blood (or plasma) flow through the forearm in units of $\mathrm{ml}$ per minute per $100 \mathrm{ml}$ of forearm, and $\mathrm{A}$ and $\mathrm{V}$ are concentrations of the metabolite in arterial and in venous blood (or plasma), respectively, in units of mass per milliliter. The technique was as described previously (1). Briefly, a double-lumen needle was inserted into the brachial artery. A polyethylene catheter was threaded into an antecubital vein and passed distally and deeply so that it sampled blood draining muscle but also, undoubtedly, adipose tissue interspersed among muscle. A second catheter was threaded into a more superficial vein, sampling mainly from skin and subcutaneous adipose tissue. Blood flow was measured by the indicator-dilution method in which Evans blue dye was injected continuously at constant rate into the brachial artery (2).

Ten young adult subjects, 6 men and 4 women, were studied. All were medical students or laboratory personnel in good health and near ideal body weight. Dietary history of carbohydrate intake was normal. No food was taken after 7 p.m. on the evening preceding the experiment. The first blood samples were obtained between 10 a.m. and noon, the last blood samples between noon and 2 p.m. All subjects were at rest at least 30 minutes prior to study. During, and for at least $5 \mathrm{~min}$ utes preceding, collection of blood samples, blood flow to the hand was occluded by a sphygmomanometer cuff about the wrist, inflated to more than $250 \mathrm{~mm} \mathrm{Hg}$ pressure.

Simultaneous sets of arterial and venous samples were collected at 15-minute intervals ( 3 sets in 8 subjects, 2 sets in the remaining 2 subjects) prior to infusion of insulin. Insulin solution was prepared from essentially glucagon-free crystalline zinc insulin (Lilly, lot T-3206). It was injected for 26 minutes at a rate that delivered $100 \mu \mathrm{U}$ of insulin per minute per $\mathrm{kg}$ body weight. Total insulin dose was always less than $0.2 \mathrm{U}$. The sphygmomanometer cuff at the wrist remained inflated during the entire 26 minutes of insulin administration. Sets of blood 
TABLE I

Mean effect of insulin on forearm metabolism *

\begin{tabular}{|c|c|c|c|c|c|c|c|c|c|}
\hline $\begin{array}{l}\text { After } \\
\text { insulin } \\
\text { started }\end{array}$ & Plasma flow & $\underset{\text { glucose }}{\text { A-V }}$ & $\stackrel{\dot{\mathrm{Q}}}{\text { glucose }}$ & $\begin{array}{c}\mathrm{A}-\mathrm{V} \\
\text { lactate }\end{array}$ & $\begin{array}{c}\mathrm{A}-\mathrm{V} \\
\mathrm{O}_{2}\end{array}$ & $\begin{array}{l}\mathrm{A}-\mathrm{V} \\
\mathrm{CO}_{2}\end{array}$ & R.Q. & $\begin{array}{c}\mathrm{A}-\mathrm{V} \\
\text { potassium }\end{array}$ & $\underset{\text { potassium }}{Q}$ \\
\hline $\min$ & $\begin{array}{c}\mathrm{ml} / \mathrm{min} / \\
100 \mathrm{ml} \text { arm }\end{array}$ & 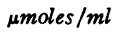 & umoles / & \multicolumn{4}{|c|}{$\mu m o l e s / m l$} & $\mu m o l e s / m l$ & $\begin{array}{c}\text { } 4 \text { moles } / \mathrm{min} / \\
100 \mathrm{ml} \text { arm }\end{array}$ \\
\hline $\begin{array}{r}0 \\
12 \\
18 \\
24 \\
45 \\
60 \\
85 \\
120\end{array}$ & $\begin{array}{l}2.1 \pm 0.14 \\
2.7 \pm 0.32 \\
2.6 \pm 0.26 \\
3.1 \pm 0.28 \\
2.7 \pm 0.24 \\
2.6 \pm 0.32 \\
2.9 \pm 0.42 \\
2.9 \pm 0.17\end{array}$ & $\begin{array}{l}0.16 \\
0.60 \\
1.11 \\
1.29 \\
1.36 \\
0.86 \\
0.55 \\
0.33\end{array}$ & $\begin{array}{l}0.59 \\
2.70 \\
4.71 \\
6.78 \\
6.07 \\
3.52 \\
2.41 \\
1.43\end{array}$ & $\begin{array}{l}-0.14 \\
-0.16 \\
-0.16 \\
-0.22 \\
-0.24 \\
-0.24 \\
-0.22 \\
-0.19\end{array}$ & $\begin{array}{l}3.5 \\
3.3 \\
3.4 \\
3.2 \\
3.4 \\
3.3 \\
2.9\end{array}$ & $\begin{array}{l}-2.5 \\
-2.0 \\
-2.3 \\
-2.4 \\
-2.5 \\
-2.4 \\
-2.1\end{array}$ & $\begin{array}{l}0.71 \\
0.61 \\
0.69 \\
0.74 \\
0.74 \\
0.73 \\
0.73\end{array}$ & $\begin{array}{r}-0.20 \\
-0.01 \\
+0.12 \\
0.17 \\
0.35 \\
0.32 \\
0.23 \\
0.13\end{array}$ & $\begin{array}{r}-0.65 \\
-0.03 \\
+0.41 \\
0.59 \\
0.95 \\
0.79 \\
0.63 \\
0.39\end{array}$ \\
\hline
\end{tabular}

* Insulin administered intra-arterially for 26 minutes beginning at time zero. Values given at time zero are means of control measurements taken before insulin infusion started. Data are means of values obtained in 10 subjects for times $0,12,18$ and 24 minutes, 9 subjects at 45 minutes, 8 at 60, 7 at 85 and 3 at 120 minutes, for everything except blood gases which were determined on 7 subjects at time $0 ; 6$ (for $\mathrm{O}_{2}$ ) and 5 (for $\mathrm{CO}_{2}$ at 12 minutes; 7 at 18 and 24 minutes; 6 at $45 ; 4$ at 60 ; and 3 at 85 minutes. SE of mean is given for plasma flow; other standard errors are

samples were collected at approximately 12 (range, 10 to $13), 18$ (16 to 20 ) and 24 (22 to 26 ) minutes after start of insulin administration. In as many cases as possible blood samples were collected after insulin administration ceased, at approximately 45 (42 to 48 ), 60 (59 to 67), 85 (75 to 90 ) and 120 minutes after insulin infusion started.

The following determinations were performed on the arterial and deep venous blood samples: hematocrit ratio, Evans blue dye concentration, serum potassium, blood glucose and lactic acid, and, in the first 7 subjects, blood $\mathrm{O}_{2}$ and $\mathrm{CO}_{2}$ content. In this series of experiments superficial venous blood was used only to test the uniformity of distribution of blue dye. All the men and one woman, Subject A, were studied during the year 1956 when analytical methods were those described previously (1). The remaining three women were studied during 1958 when we used a glucose oxidase method for determining blood glucose concentration and a lactic acid dehydrogenase method for blood lactate. These methods were examined extensively and validated thoroughly in our hands but are essentially only minor modifications of those described by others $(3,4)$.

\section{RESULTS}

Results appear in Table I.

Insulin concentration in forearm plasma. This is simply the ratio of the known rate of injection of insulin to forearm plasma flow measured by Evans blue dye. It varied from 200 to $500 \mu \mathrm{U}$ per $\mathrm{ml}$ among the men and from 300 to $700 \mu \mathrm{U}$ per $\mathrm{ml}$ among the women. At the time these studies were first undertaken we believed that we were simply doubling the endogenous concentration of insulin. From the subsequent work of Yalow and Berson (5), these are about ten times the normal concentration of insulin in the basal state but approximately the same as the concentration of insulin in plasma appearing in response to glucose administration.

Blood flow. It is essential to proper employment of the Fick principle, on which much of this work is based, that blood flow be constant. Unfortunately, it was not until late 1956 after the first six subjects were studied that we learned that mechanical disturbance, transmitted along the arterial needle during sampling, caused a subsequent, often profound but erratic, vasodilatation. Blood flow usually returned to normal well within the 15-minute interval between our usual control samples, but with more frequent sampling during infusion of insulin a sustained but variable increase in blood flow often occurred. This iatrogenic vasodilatation was avoided by connecting the sampling syringe to the arterial needle through a coil of polyethylene tubing, so that motion was not transmitted importantly through the needle to the artery.

Several regrettable consequences of vasodilatation occur. In the first place, during changes in blood flow it is improper to calculate $\dot{Q}$ in the usual fashion. In the second place, there are some suggestions that uptake and output of certain metabolites, oxygen in particular, may be, within limits, blood flow- or supply-dependent $(6,7)$. This implies that, even if blood flow becomes constant at some abnormally high level, there may be an increase in $\dot{Q}, \mathrm{~A}-\mathrm{V}$ differences remaining constant, and the high $\dot{Q}$ may be owing only to increased blood flow and not to insulin. In the third place, the artifact occurred during the time 
when all the men and only one of the women were studied, giving the illusion that insulin increased flow in men but not in women. Furthermore, since the response of $\mathrm{A}-\mathrm{V}$ differences to insulin was the same in men as in women, the products of $\mathrm{A}-\mathrm{V}$ differences and blood flows tended to be higher in men than in women, making it appear, probably falsely, that men were more sensitive to insulin than are women.

Despite our dissatisfaction with our measurements of blood flow, it is unfortunately true that the few data published by others, in which flow was measured by venous occlusion plethysmography, show even greater variation in blood flow than we found $(8,9)$. Although, on the average, blood flow increased during and after insulin administration compared with the control period, once blood flow increased it remained reasonably constant from minutes 12 to 120 after infusion of insulin began.

Arterial concentration (Figure 1). Not only does rigid attention to the Fick principle demand that arterial concentration be constant, but it is also desirable that there be no changes in arterial concentration that might provoke systemic counterregulatory processes such as secretion of epinephrine. There were no statistically significant changes in arterial concentrations. Mean changes in arterial glucose, lactate, and potassium concentrations were in the direction expected during and after insulin administration but were small (less than 2 per cent of arterial concentration for glucose, less than 5 per cent for lactate, and less than 0.5 per cent for potassium).

Glucose (Figure 2). There is no doubt that insulin increased glucose uptake and that the effect occurred promptly. In nine of the ten subjects glucose $\mathrm{A}-\mathrm{V}$ difference and $\dot{Q}$, measured at 12 minutes, exceeded the control differences. In six subjects blood flow during collection of this specimen was within 20 per cent of control values, so that the calculation of $\dot{Q}$, which was fivefold greater than control values, is reasonable. Although the peak effect was reached either just be-

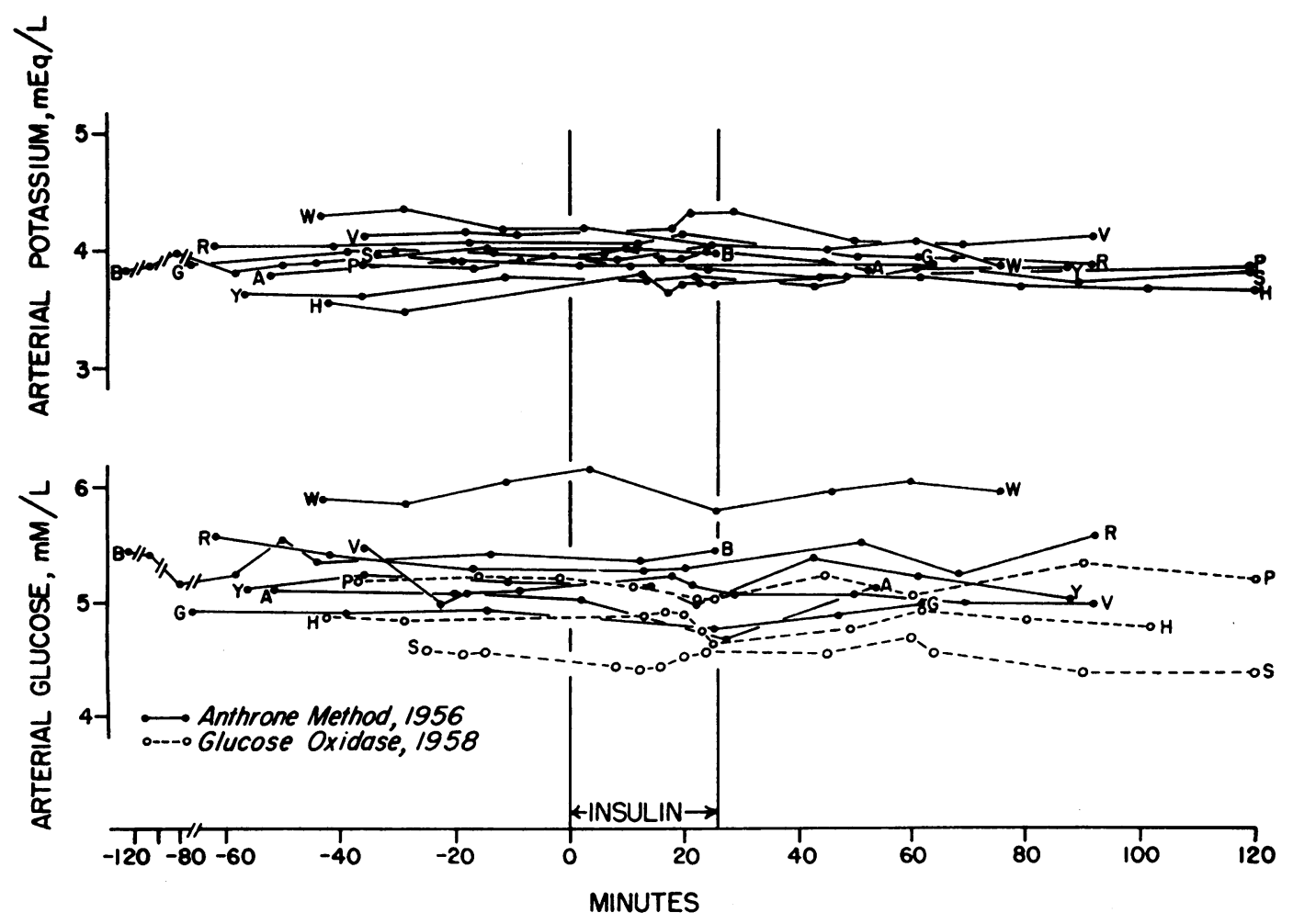

Fig. 1. LACK OF SYSTEMIC EFFECT OF INTRA-ARTERIAL INSUlin on CONCENTRATION of Potassium in ARTERIal plasma and of GLUCOSE IN ARTERIal BLOOd. Each of the 10 subjects is identified by an initial. 


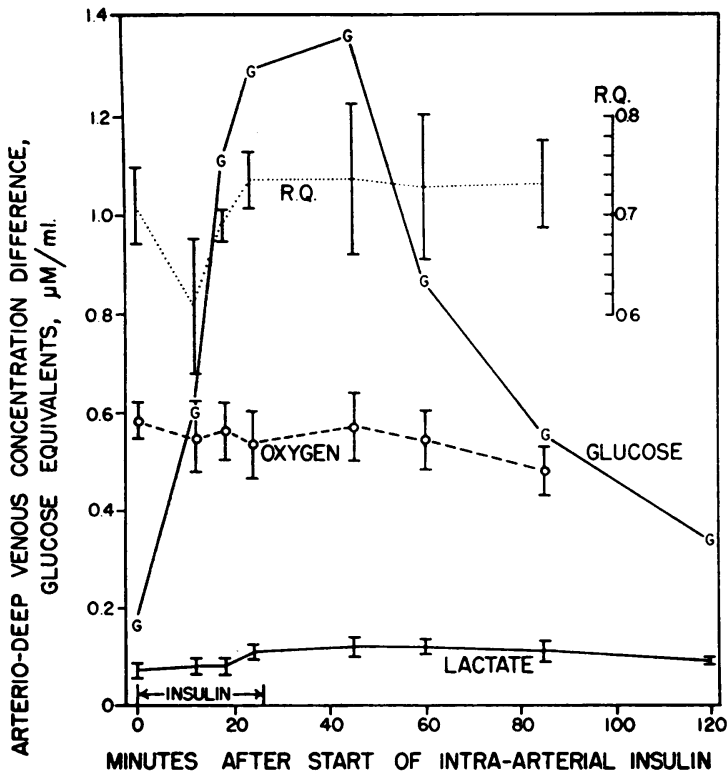

Fig. 2. ARteriovenous Differences ACross THE FOREARM IN RESPONSE TO INTRA-ARTERIAL INSUlin. Data at zero time are means of all samples taken before insulin administration. Data are plotted as mean $\pm \mathrm{SE}$ of mean, except for glucose, for which only mean A-V difference is plotted (see Figure 3 for $\mathrm{SE}$ of mean for glucose). To convert oxygen A-V difference to absolute scale multiply ordinate by 6 ; to convert lactate to absolute scale multiply ordinate by 2 .

fore the end of the infusion, at 24 minutes, or with the next sample, 19 minutes after cessation of insulin injection, the effect of insulin at $18 \mathrm{~min}$ utes was only about 20 per cent less than the maximum. The effect of insulin, as measured by A-V difference, decayed rapidly, returning halfway to control levels between the 60- and 85-minute samples. By interpolation, 50 per cent decay occurred at about 65 minutes. Owing to uncertainties about the effect of altered blood flow, there is some doubt about the magnitude of glucose uptake in response to insulin. If blood flow had remained constant, judged from the increase in $\mathrm{A}-\mathrm{V}$ difference, maximal glucose uptake in response to insulin would have been about nine- or tenfold greater than control values. With the exception of the female subject $P$, peak glucose uptake in response to insulin was always at least $5 \mu$ moles per minute per $100 \mathrm{ml}$ of forearm, even in those subjects in whom blood flow was not changed by more than 20 per cent.

Lactate (Figure 2). There was a small but definite increase in lactate $\mathrm{A}-\mathrm{V}$ difference during and after administration of insulin, not detectable until 24 minutes after the start of the insulin infusion. Despite the increase in lactate production, because glucose uptake increased to a greater extent, the fraction of glucose uptake accounted for by lactate production actually decreased during and after administration of insulin, from a control value of 42 per cent to an average of less than 10 per cent.

$\mathrm{O}_{2}, \mathrm{CO}_{2}$ and respiratory quotient (Figure 2). $\mathrm{A}-\mathrm{VO}_{2}$ differences were unaffected by insulin. Because blood flow was increased, calculated $\mathrm{Q}_{\mathrm{O}_{2}}$ increased proportionately for the group as a whole. However, in those subjects in whom blood flow was acceptably stable, $\dot{Q} \mathrm{o}_{2}$ was unchanged by insulin. It is concluded, therefore, that insulin probably exerted no direct effect on oxidation and that no increase in $\dot{Q}_{2}$ accompanied or followed, during the time of these observations, the increased glucose uptake produced by insulin.

Except at minute 12 after onset of insulin infusion, $\mathrm{CO}_{2} \mathrm{~A}-\mathrm{V}$ differences were similarly unaffected by insulin. Mean $\mathrm{CO}_{2} \mathrm{~A}-\mathrm{V}$ difference at the first sample after insulin infusion began was 20 per cent less than the mean control A-V difference, a significant and unexplained decrease.

Respiratory quotient remained low throughout the experiment and provided no clue that glucose oxidation was added to or substituted for oxidation of lipid in the presence of insulin. Owing to the decrease in $\mathrm{CO}_{2} \mathrm{~A}-\mathrm{V}$ difference at time 12 minutes, the R.Q. at 12 minutes, 0.61 , was significantly less than the control and than subsequent R.Q.'s. For the five subjects in whom R.Q. was measured at 12 minutes, mean decrease in R.Q. was $0.052 \pm 0.017$ at 12 minutes compared with that at time zero.

$(G-L) / O_{2}$. If glucose, removed from arterial blood by forearm tissues but not accounted for by lactate production ( $G$ minus $L$ ), were all oxidized, the fraction of observed $\mathrm{O}_{2}$ consumption accounted for by glucose oxidation, (G-L) $/ \mathrm{O}_{2}$, during the control period was 0.19 , similar to the mean value of 0.16 in a group of 43 normal subjects (10). During and after insulin infusion this fraction was well above unity; that is, more than enough glucose was abstracted by muscle to account for all of its $\mathrm{O}_{2}$ consumption. In fact, however, there was no evidence from either $\dot{\mathrm{Q}}_{2}$ or R.Q. that the incremental glucose abstracted in response to in- 


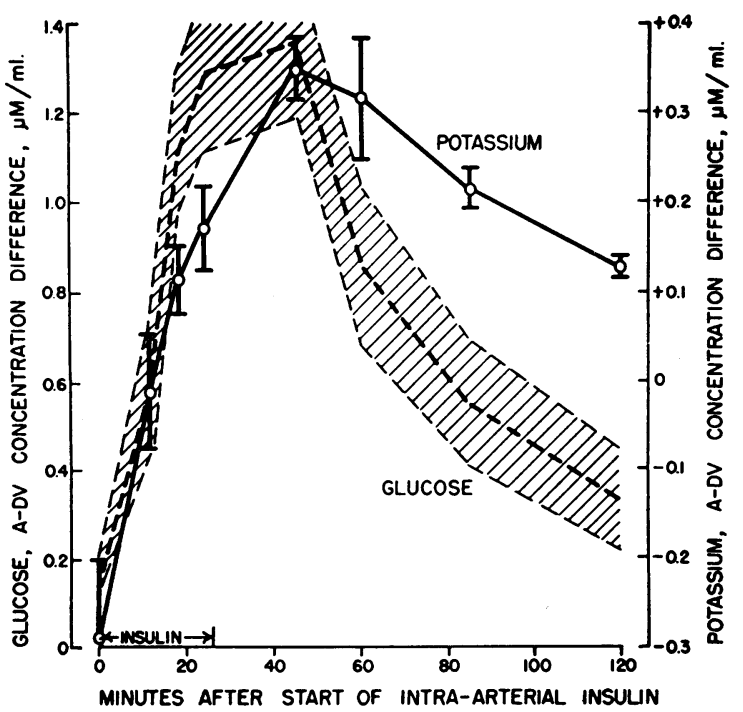

Fig. 3. Difference in time course between ReSPONSE OF POTASSIUM AND OF GLUCOSE TO INSULIN. Shaded area gives range of mean $\pm \mathrm{SE}$ of mean for glucose; mean glucose A-V difference is given by dashed line. Potassium is plotted as mean $\pm \mathrm{SE}$ of the mean.

sulin was oxidized. It is concluded that glucose taken up by muscle in response to insulin is stored, presumably largely as glycogen.

Potassium (Figure 3). In the basal state with the arm at rest, $\mathrm{K}$ moves out of forearm muscle into venous blood during the middle and late morning (11). This observation was confirmed in the present group of ten subjects, in nine of whom venous $K$ concentration exceeded arterial. Mean K A-V difference was $-0.29 \mathrm{mEq}$ per L and mean $\mathrm{K}$ output was $0.65 \mu \mathrm{Eq}$ per minute per $100 \mathrm{ml}$ of forearm, both figures being slightly larger (more negative) than those in our larger groups of 73 and 61 normal subjects. With the first 12-minute sample after infusion of insulin began, venous $K$ concentration fell in all ten subjects and $\mathrm{A}-\mathrm{V}$ difference became positive in half of them. From then on mean $\mathrm{K} \mathrm{A}-\mathrm{V}$ difference was positive. Although movement of $\mathrm{K}$ from arterial blood into muscle appeared as promptly as that of glucose in response to insulin, the subsequent time course was quite different. Peak effect with respect to $\mathrm{K}$ uptake was delayed compared with that of glucose, and the decline in $\mathrm{K}$ uptake was much slower than that of glucose uptake. Half-time of decay of insulin effect on glucose uptake was about 65 minutes. Half-decay of insulin effect on $\mathrm{K}$ uptake was not reached in 85 minutes and was not even attained in 120 minutes in the three subjects in whom data were obtained at that time.

Ratio of insulin effect on glucose uptake to insulin effect on $\mathrm{K}$ uptake was inconstant. The ratios were inconsistent with the notion that glucose entered muscle as the $\mathrm{K}$ salt of a glucose phosphate, in which case between 1 and 2 moles of $\mathrm{K}$ should move with each mole of glucose, as suggested implicitly or explicitly by several authors [for example (12)], and the ratios and the promptness of the response were inconsistent with the notion that $\mathrm{K}$ moved into muscle with water as glycogen was deposited, in accordance with Fenn's observations (13), in which case $1 \mathrm{mEq}$ of $\mathrm{K}$ is said to accumulate for each 15 mmoles of glucose. Too little $\mathrm{K}$ moved into muscle to support the first hypothesis and too much $\mathrm{K}$ moved into muscle to support the second. From Fenn's data, $1 \mathrm{~g}$ of "dry glycogen" exists in muscle as $2.46 \mathrm{~g}$ of "wet glycogen" (14). During the hour after insulin infusion began, if all glucose abstracted from blood were deposited as glycogen, there would have been $30 \mathrm{mg}$ of "dry glycogen" or an additional $48 \mathrm{mg}$ of cell water per $100 \mathrm{ml}$ of forearm. This increase in cell water would account for accumulation of only about $6 \mu \mathrm{Eq}$ of $\mathrm{K}$, less than one-tenth the amount taken up in fact.

Hematocrit. Mean hematocrit ratio A-V difference was indistinguishable from zero (mean. 0.18 per cent) and was unaffected by insulin (mean A-V difference, 0.18 per cent).

\section{DISCUSSION}

There has been a number of reports on the effects of insulin on arteriovenous or on capillaryvenous differences in glucose concentration in man and in laboratory animals since the original publications by Frank, Nothmann and Wagner (15) and by Cori and Cori (16). In all but one, insulin was administered in such fashion as to alter arterial glucose concentration. Even when it was given intra-arterially the dose was so large that the effect was like that of an intravenous dose $(15,17,18)$. When arterial glucose concentration changes it is difficult, and even impossible with only the data available, to quantify the effect of insulin. This is because $a$ ) the falling ar- 
terial glucose concentration is a stimulus to counter-regulatory mechanisms, particularly to secretion of epinephrine, and one cannot distinguish effects of insulin from those of counterregulating agents by this technique alone; and $b$ ) simultaneous $\mathrm{A}-\mathrm{V}$ differences (which in the steady state equal $\dot{Q} / F$ or uptake per unit blood flow), owing to the fact that time is required for glucose to travel from arterial to venous blood, overestimate $\dot{Q} / F$ while arterial concentration rises and underestimate $\dot{Q} / F$ while arterial concentration falls. For these reasons most previous studies have underestimated the immediate effect of insulin on peripheral uptake of glucose.

Although it is obvious that $\mathrm{A}-\mathrm{V}$ difference is not a measure of glucose uptake unless blood flow is known, the literature refers repeatedly to glucose A-V difference as though it were glucose uptake and only occasionally has blood flow been measured. It has been stated, but without documentation, that even when insulin produces hypoglycemia in man there is no change in forearm blood flow measured plethysmographically (18). This is contrary to three other reports in which insulin-induced hypoglycemia was associated with marked alterations in peripheral blood flow, again measured plethysmographically (19-21). In any event, it is hazardous not to incorporate blood flow measurements into the experiment and impossible to quantify the effect of insulin without them.

There are two reports by Hardwick and Butterfield and their colleagues $(8,22)$ of experiments in which blood flow (measured plethysmographically) and glucose A-V differences were determined after intra-arterial insulin. Although the concentration of insulin in brachial arterial plasma in Butterfield's experiments was up to ten times that in ours, it is stated, but without presentation of data, that arterial glucose concentrations were constant (8), perhaps owing to the fact that intra-arterial injection was "brief" (22) or of only 2 minutes' duration (8). When glucose response was at its peak it was only half as great in Butterfield's experience (8) as in ours even though the concentration of insulin in forearm plasma was ten times as great in the forearm experiments. Presumably the greater responsiveness in our subjects is the result of the longer period of injection. Hardwick, Butterfield, Fry and Briggs (8). though not reporting their measurements of blood flow, state that threefold variations were seen regularly, even during control periods, when flow was estimated by venous-occlusion plethysmography. We are not accustomed to seeing such changes during control periods when flow is measured by the indicator-dilution method, and the changes in blood flow which disturbed us were increases of approximately 50 per cent, occurring in some subjects during and after administration of insulin. Although, in our subjects, forearm plasma flow was increased by about one-third on the average, during and after insulin, compared with that during control periods, mean plasma flow (Table I) was acceptably constant during and after insulin, varying over a range of only 18 per cent.

Despite difficulties in quantifying glucose uptake, owing to disturbances in blood flow produced artificially by the technique of the experiment in our early group of subjects, it is clear that an intra-arterial infusion of insulin, achieving forearm plasma concentration of several hundred $\mu \mathrm{U}$ per $\mathrm{ml}$, produced profound local effects on glucose uptake, probably increasing it by about tenfold above resting values, with little or no systemic effect measured by changes in arterial concentration. The effect of insulin on glucose uptake was. within the experimental limitation of the method, immediate. Only a minor fraction of glucose abstracted from blood in response to insulin was accounted for by lactate production, and none of it appeared to have been oxidized during the course of these observations. It is probable that most of it was deposited in forearm muscles as glycogen. suggesting that either insulin or some change in intracellular environment produced by insulin stimulates glycogen synthesis, supporting the report by Villar-Palasi and Larner (23) that UDPG glycogen transglucosylase activity from rat diaphragms is increased when the diaphragms have been incubated with insulin.

Insulin causes $\mathrm{K}$ to move in the net from arterial plasma to muscle. The effect is as prompt as the effect of insulin on glucose movement but is clearly dissociated temporally from the latter. Insulin-induced $\mathrm{K}$ uptake does not seem explicable by the classic hypotheses that it is linked to glucose uptake either through its entry into cells as a 
K-glucose-phosphate or through its entry into cells with an increase in cell water associated with deposition of glycogen. It has been proposed, from measurements of changes in electrical potential across mammalian muscle fiber membranes and from measurements of changes in $\mathrm{K}$ flux, that $\mathrm{K}$ uptake by muscle in response to insulin is secondary to a change in the fixed electrical charge within the membrane produced by the association of insulin and the membrane (24). Movement of $\mathrm{K}$ induced by insulin is not consequent upon glucose movement, since it occurs in the absence of glucose (25), but represents an effect of insulin parallel to that which hastens glucose entry. In this view, the same association between insulin and membrane that, hypothetically, alters the membrane fixed charge also, hypothetically, deforms the membrane, increasing its permeability with respect to glucose.

There has been some discussion from time to time concerning the relative responsiveness of the liver and of muscle to insulin. We have no observations referable to hepatic responsiveness but our data make it clear that the forearm of man is exquisitely sensitive to insulin in concentrations much less than those used previously by others to study either hepatic or peripheral effects.

\section{SUMMARY}

Insulin, injected continuously at constant rate into the brachial artery at a final concentration of 200 to $700 \mu \mathrm{U}$ per $\mathrm{ml}$ of brachial arterial plasma, increased forearm glucose uptake promptly and ultimately by about tenfold. There was no evidence that any but a minor fraction of this additional glucose uptake was dissimilated to lactate and $\mathrm{CO}_{2}$ during the 1.5 to 2 hours after onset of insulin infusion.

Under the same conditions, insulin provoked $\mathrm{K}$ uptake by forearm tissues as promptly as it promoted glucose entry but, on the basis of the relative magnitudes of $\mathrm{K}$ and of glucose uptake and of the differences in their time course, classic hypotheses relating these two effects of insulin appear untenable.

\section{ACKNOWLEDGMENT}

We are indebted to those who volunteered for these experiments and to Misses Ellen Rogus and Sara Ann
Verplanck, Mrs. Gerda von Ahlefeldt and Mrs. James Cullen for technical assistance.

\section{REFERENCES}

1. Andres, R., Cader, G., and Zierler, K. L. The quantitatively minor role of carbohydrate in oxidative metabolism by skeletal muscle in intact man in the basal state. Measurements of oxygen and glucose uptake and carbon dioxide and lactate production in the forearm. J. clin. Invest. 1956, 35, 671.

2. Andres, R., Zierler, K. L., Anderson, H. M., Stainsby, W. N., Cader, G., Ghrayyib, A. S., and Lilienthal, J. L., Jr. Measurement of blood flow and volume in the forearm of man; with notes on the theory of indicator-dilution and on production of turbulence, hemolysis, and vasodilatation by intravascular injection. J. clin. Invest. 1954, 33, 482.

3. McCann, W. P., and Jude, J. R. The synthesis of glucose by the kidney. Bull. Johns Hopk. Hosp. $1958,103,77$.

4. Horn, H. D., and Bruns, F. H. Quantitativ Bestimmung von $\mathrm{L}(+)$-Milchsäure mit Milchsauredehydrogenase. Biochim. biophys. Acta 1956, 21, 378.

5. Yalow, R. S., and Berson, S. A. Immunoassay of endogenous plasma insulin in man. J. clin. Invest. 1960, 39, 1157.

6. Nakamura, $H$. The oxygen use of muscle and the effect of sympathetic nerves on it. J. Physiol. (Lond.) 1921, 55, 100.

7. Pappenheimer, J. R. Blood flow, arterial oxygen saturation, and oxygen consumption in the isolated perfused hindlimb of the dog. J. Physiol. (Lond.) 1941, 99, 283.

8. Hardwick, C., Butterfield, W. J. H., Fry, I. K., and Briggs, J. H. Direct measurement of the effect of insulin on the uptake of glucose by peripheral muscles in normal subjects, diabetics and acromegalics. Proc. roy. Soc. Med. 1959, 52, 807.

9. Butterfield, W. J. H., and Holling, H. E. Peripheral glucose metabolism in fasting control subjects and diabetic patients. Clin. Sci. 1959, 18, 147.

10. Baltzan, M. A., Andres, R., Cader, G., and Zierler, K. L. Heterogeneity of forearm metabolism with special reference to free fatty acids. J. clin. Invest. 1962, 41, 000.

11. Andres, R., Cader, G., Goldman, P., and Zierler, K. L. Net potassium movement between resting muscle and plasma in man in the basal state and during the night. J. clin. Invest. 1957, 36, 723.

12. Mackler, B., Lichtenstein, H., and Guest, G. M. Effects of ammonium chloride acidosis on the action of insulin in dogs. Amer. J. Physiol. 1951, 166, 191.

13. Fenn, W. O. The deposition of potassium and phosphate with glycogen in rat livers. J. biol. Chem. 1939, 128, 297.

14. Fenn, W. O., and Haege, L. F. The deposition of glycogen with water in the livers of cats. J. biol. Chem. 1940, 136, 87. 
15. Frank, E., Nothmann, M., and Wagner, A. Extrahepatische Wirkung des Insulins beim Zuckerverbrauch. Klin. Wschr. 1924, 3, 581.

16. Cori, C. F., and Cori, G. T. Comparative study of the sugar concentration in arterial and venous blood during insulin action. Amer. J. Physiol. 1925, 71, 688.

17. Bell, D. M., and Burns, T. Effect on femoral A-V glucose difference of insulin injected into an antecubital vein and into a femoral artery. J. clin. Invest. 1952, 31, 717.

18. Ginsburg, J., Galbraith, H.-J. B., and Paton, A. Some peripheral effects of insulin and other hormones in man in The Mechanism of Action of Insulin, F. G. Young, W. A. Broom, and F. W. Wolff, Eds. Oxford, Blackwell, 1960, p. 225.

19. Abramson, D. I., Schkloven, N., Margolis, M. N., and Mirsky, I. A. Influence of massive doses of insulin on peripheral blood flow in man. Amer. J. Physiol. 1939, 128, 124.
20. French, E. B., and Kilpatrick, R. The role of adrenaline in hypoglycaemic reactions in man. Clin. Sci. 1955, 14, 639.

21. Allwood, M. J., Ginsburg, J., and Paton, A. The effect of insulin hypoglycaemia on blood flow in intact and sympathectomized extremities in man. J. Physiol. (Lond.) 1957, 139, 97.

22. Butterfield, J., Fry, I. K., and Holling, E. Effects of insulin, tolbutamide and phenethyldiguanidine on peripheral glucose uptake in man. Diabetes 1958, 7, 449.

23. Villar-Palasi, C., and Larner, J. Insulin treatment and UDPG glycogen transglucosylase activity. Fed. Proc. 1960, 19, 164.

24. Zierler, K. L. Effect of insulin on membrane potential and potassium content of rat muscle. Amer. J. Physiol. 1959, 197, 515.

25. Zierler, K. L. Effect of insulin on potassium efflux from rat muscle in the presence and absence of glucose. Amer. J. Physiol. 1960, 198, 1066. 